\title{
Punica granatum and amygdalin extracts plus cobalamin combined with albendazole reduce larval burden and myositis in experimental trichinosis
}

\author{
Extratos de Punica granatum e amígdalina mais cobalamina combinado com \\ albendazol reduzem a carga larvar e a miosite na triquinose experimental
}

\author{
Marwa Esmat ${ }^{1}$ (D); Amany Ahmed Abdel-Aal2,3 (D); Maisa Ahmed Shalaby ${ }^{4}$ (D); \\ Mennat-Elrahman Ahmed Fahmy4* (1); Manal Abdel Magid Badawi ${ }^{5}$ (1); Marwa Adel Elmallawany ${ }^{2}$ (1); \\ Mona Magdy ${ }^{7}$; ; Adam Ashraf Afife ${ }^{6}$ (D); Iman Raafat Abdel Shafi² (D) \\ 'Department of Medical Parasitology, Faculty of Medicine, Misr University for Science and Technology, $6^{\text {th }}$ October city, Egypt \\ 2Department of Medical Parasitology, Faculty of Medicine, Cairo University, Cairo, Egypt \\ ${ }^{3}$ Department of Postgraduate Studies \& Scientific Research, Armed Forces College of Medicine - AFCM, Cairo, Egypt \\ ${ }^{4}$ Medical Parasitology Department, Theodor Bilharz Research Institute - TBRI, Giza, Egypt \\ ${ }^{5}$ Department of Pathology, National Research Center, Giza, Egypt \\ ${ }^{6}$ College of Life Sciences, Faculty of Medicine, Leicester University, Leicester, United Kingdom \\ ${ }^{7}$ Department of Pathology, Theodor Bilharz Research Institute - TBRI, Giza, Egypt
}

How to cite: Esmat M, Abdel-Aal AA, Shalaby MA, Fahmy MEA, Badawi MAM, Elmallawany MA, et al. Punica granatum and amygdalin extracts plus cobalamin combined with albendazole reduce larval burden and myositis in experimental trichinosis. Braz J Vet Parasito/ 2021; 30(4): e012021. https://doi.org/10.1590/S1984-29612021084

\begin{abstract}
Trichinellosis is a zoonosis results from eating raw or semi-cooked meat of infected animals. Medicinal plants have been used lately as alternatives and/or combined therapies to resolve some drawbacks of the current regimens. This work analyzed the effect of albendazole monotherapy on Trichinella spiralis experimental infection (group A), in comparison to $P$. granatum and amygdalin extracts + cobalamin (group B), plus its combination with albendazole (group C). The study revealed that the extracts alone or combined with albendazole had an inferior effect to albendazole monotherapy regarding number of adult worms $(40.83 \pm 3.82,18.67 \pm 1.86$ and $16.83 \pm 2.32$, respectively). However, their effect was more obvious in muscle phase combined with albendazole, achieving the lower number of larvae/mL tissue homogenate ( $22.33 \pm 3.27$ in comparison to $39.67 \pm 2.58$ achieved by albendazole monotherapy). The extracts exerted a significant immunomodulatory effect by reducing the local CD4+ expression in the intestine as well as in muscle phase $(1.15 \pm 0.25$ and $3.80 \pm 0.65$ in comparison to $4.97 \pm 0.37$ and $12.20 \pm 0.87$ with albendazole monotherapy, respectively). So, these extracts improved the therapeutic efficacy of albendazole, specifically in muscle phase and counteracted the inflammatory reaction caused by albendazole monotherapy, thus extensively alleviating the resulting myositis.
\end{abstract}

Keywords: Trichinosis, Punica grantaum, amygdalin, cobalamin, albendazole, muscle phase.

\section{Resumo}

Trichinellosis é uma zoonose resultante da ingestão de carne crua ou semicozida de animais infectados. As plantas medicinais têm sido usadas, ultimamente, como alternativas e/ou terapias combinadas, para resolver algumas desvantagens dos regimes atuais. Este trabalho analisou o efeito da monoterapia albendazole na infecção experimental por Trichinella spiralis (grupo A), em comparação com extratos de P. granatum e amígdalina +cobalamina (grupo B), além de sua combinação com albendazol (grupo C). O estudo revelou que os extratos sozinho ou combinado com albendazol teve efeito inferior à monoterapia albendazol em relação ao número de vermes adultos $(40,83 \pm 3,82,18,67 \pm 1,86$ e 16,83 $\pm 2,32$, respectivamente). No entanto, seu efeito foi mais óbvio na fase muscular combinado com o albendazol, alcançando o menor número de larvas $/ \mathrm{mL}$ homogeneizado de 
tecido (22,33 $\pm 3,27$ em comparação com 39,67 $\pm 2,58$ obtidos pela monoterapia albendazol). Os extratos exerceram um efeito imunomodulatório significativo, ao reduzir a expressão local CD4+ no intestino, bem como na fase

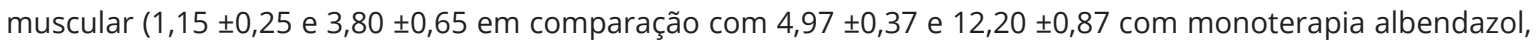
respectivamente). Assim, esses extratos melhoraram a eficácia terapêutica do albendazol, especificamente na fase muscular e neutralizaram a reação inflamatória causada pela monoterapia albendazol, aliviando extensivamente a miosite resultante.

Palavras-chave: Trichinose, Punica grantaum, amígdalina, cobalamina, albendazol, fase muscular.

\section{Introduction}

Trichinellosis or trichinosis is an emerging and reemerging zoonotic disease in many countries. Transmission occurs through consumption of the specific nematode larvae in raw or semi-raw meat and meat-derived products of infected animals, most commonly domestic and wild swine (Bai et al., 2017; Conlan et al., 2014). While infection can develop in a broad variety of mammalian hosts, the different cultural eating habits represent the main risk factor for human infections (Pozio, 2007; Gottstein et al., 2009).

Trichinella spiralis, a member of the encapsulated clade, is the most characterized species in the Trichinella genus, being of high prevalence and an important cause of human infections. Moreover, it is readily infective for laboratory animals; providing valuable models to understand various aspects of the infection (Pozio \& Zarlenga, 2013; Sofronic-Milosavljevic et al., 2015). All developmental stages of the parasite are found in the same host. $T$. spiralis infection starts with a brief intestinal phase, where the infective larvae (L1) mature into adult worms which in turn release the migrating newborn larvae (NBL). During this phase a mixed immune response is induced with initial Th1 control followed by a protective Th2 predominance resulting in the expulsion of adult worms (llic et al., 2012). The muscular phase ensues with NBL reaching skeletal muscle, where they develop into L1, and modify the muscle cell architecture in order to survive in the host for several months up to years. The chronic stimulation of the immune system through the parasite excretory-secretory products (ES) is thought to activate regulatory elements; such as regulatory T cells (T-regs) which were observed near the infected cells, furthermore, TGF- $\beta$ and IL-10 are documented to promote persistence of infection (llic et al., 2012; Sun et al., 2019).

Trichinellosis is a serious disease with no satisfactory treatment and the clinical course can range from an asymptomatic form to being fatal. Benzimidazoles: albendazole and mebendazole, are the principal anthelminthics used in treatment of this infection (Gottstein et al., 2009). Both drugs demonstrate weak activity against encapsulated larvae. The effectiveness of therapy depends on the time of administration, being highly effective within 1 week after the infection, during the intestinal phase. The later the drug is administered the greater the probability that larvae will remain viable for years in human hosts despite treatment (Dupouy-Camet et al., 2002; Gottstein et al., 2009). This downside of the current treatment highlights the need for novel effective and safe anti-trichinellosis drugs (Shalaby et al., 2010; Yadav \& Temjenmongla, 2012).

The use of medicinal plants has gained increasing attention lately, with various plant extracts being the subject of many pharmacological studies. Punica granatum, commonly known as the pomegranate, is a fruit with rich ethnomedical applications frequently grown in the Mediterranean region. Described as the nature's power fruit, P. granatum extracts were reported to have potent antioxidant and anti-inflammatory properties. In addition they were introduced as potential anti-microbial and anthelminthic agents (Al-Megrin, 2017; Dkhil, 2013). Another naturally occurring compound, amygdalin, referred to as vitamin B17, is a cyanogenic glycoside found in fruit kernels of members of the Rosaceae family such as almonds, apricots and peaches. Amygdalin and its semi-synthetic derivative, laetrile, have been labelled as controversial antineoplastic agents over the past century (Juengel et al., 2016; Saleem et al., 2018). Amygdalin is reported to be involved in the regulation of apoptosis, adhesion molecules and cell cycle elements in addition to its inhibitory effect on the expression of inflammatory cytokines. Additionally, amygdalin was proposed to have antifibrotic effect, and a stimulatory impact on muscle growth (Liczbiński \& Bukowska, 2018). The present study aimed at investigating the effect of pomegranate $P$. granatum and amygdalin extracts on both the intestinal and muscular phases of $T$. spiralis infection in mice in comparison with albendazole monotherapy as a reference drug. 


\section{Materials and methods}

\section{Experimental animals and investigational infection}

Female mice BALB/c mice (25-30 g) aged six-eight weeks were purchased from the Animal Center of Theodor Bilharz research Institute "TBRI", following the institutional code of ethics for animal research.

The experiment was approved by ethical committee at Theodor Bilharz Research Institute (Approval code: 2020/FWA00010609).

Mice were maintained in this study in a controlled environment (12:12 $\mathrm{h} \mathrm{light/dark} \mathrm{photocycle} \mathrm{with} \mathrm{a} \mathrm{temperature}$ of $22 \pm 2{ }^{\circ} \mathrm{C}$ and a relative humidity of 55\%). The mice were infected orally with about 300 larvae per mouse. The strain of $T$. spiralis was originally isolated from the diaphragms of infected mice reared in TBRI, Cairo. The infected diaphragms were minced and digested in $1 \%$ pepsin-hydrochloride. After overnight incubation at $37^{\circ} \mathrm{C}$, larvae were collected using the sedimentation technique, washed in physiological saline $(0.85 \%)$ several times, and the number of larvae per $\mathrm{mL}$ homogenate was counted and prepared for animal infection (Dunn \& Wright, 1985).

\section{Study groups}

Infected mice were classified into three main groups (added to a control infected non-treated group/each phase); $A, B$, and C, each subdivided into two subgroups (I and II) intestinal and muscular phases, 10 mice per subgroup (Cui et al., 2008; Zhang et al., 2010). Group A; infected treated with full dose albendazole, Group B; P. granatum + amygdalin + cobalamin and Group C; half dose albendazole + P. granatum + amygdalin + cobalamin. Assessment of results was done using parasitological examination by counting adult worms in the intestine on the 7 th day post infection (dpi), and larval count in the muscles on the $45^{\text {th }} \mathrm{dpi}$.

\section{Drugs and herbal treatment}

\section{Reference drug}

Albendazole was supplied as suspension, $20 \mathrm{mg} / \mathrm{mL}$, from the Egyptian International Pharmaceutical Industries Co. in a dose $50 \mathrm{mg} / \mathrm{kg}$. For each mouse, $20 \mathrm{mg} / \mathrm{mL}$ was prepared and given orally ( $50 \mathrm{mg} / \mathrm{kg}$ ) from the $2^{\text {nd }} \mathrm{dpi}$ for 3 successive days.

\section{Plant supplies, extracts and dose preparation}

In order to prepare fresh extracts, fresh pomegranates (500 g) were obtained from a public market. Peeling of the pomegranate was performed to be separate the peel from the flesh. The peels were then oven dried at $33^{\circ} \mathrm{C}$ for 7 days. Following this the dried peels were powdered in an electric grinder and stored in plastic bags at $4{ }^{\circ} \mathrm{C}$ for the next step. In concordance with Moneim et al. (2011), powdered plant materials were extracted with $70 \%$ ethanol at room temperature by maceration and then filtered. The filtrates were concentrated under vacuum using a rotary evaporator. The obtained solvent-free residue of the plant extract was stored at $4^{\circ} \mathrm{C}$ for subsequent preparation of the required doses. Plant extracts were freshly prepared before usage by suspending $1 \mathrm{~g}$ of each extract in $50 \mathrm{~mL} 3 \%$ tween 80 dissolved in $0.9 \%$ saline and $60 \mathrm{mg} / \mathrm{kg} /$ day was given/mouse orally via gavage at the day of infection and continued every day till the end of the experiment.

\section{Amygdalin}

In concordance with Moslehi et al. (2018), the purified powder form of the supplement was given orally $50 \mathrm{mg} / \mathrm{kg}$, diluted in $0.2 \mathrm{~mL} 0.9 \%$ saline solution, LKT Laboratories, Inc. (St. Paul, MN, USA) and the dose was given daily until the end of the experiment.

\section{Parasitological analysis}

Adult parasites were collected and counted in intestinal phase subgroups. In concordance with (Wakelin \& Lloyd, 1976), following mice euthanasia the small intestines were isolated and washed in physiological saline, then divided into $1 \mathrm{~cm}$ segments. Intestinal segments were incubated in physiological saline at $37^{\circ} \mathrm{C}$ for 2 hours, and then washed 3 times, taking 
into account that all the solutions from the previous step were collected to be centrifuged for 3 minutes at $2000 \mathrm{rpm}$. The number of adults in the sediment was counted under an inverted microscope using low power magnification $\times 100$. Larvae were collected and counted from muscular phase subgroups. Muscle tissue was digested as mentioned above in $1 \%$ pepsin/1\% $\mathrm{HCl}$ according to (Dunn \& Wright, 1985), larvae were recovered and counted under an inverted microscope.

\section{Histopathological examination}

Intestinal specimens $(1 \mathrm{~cm}$ from the small intestine at the junction of the proximal $1 / 3$ and distal $2 / 3$ ) were taken from mice sacrificed on the $7^{\text {th }} \mathrm{dpi}$, while skeletal muscle specimens from the hind legs were taken from mice sacrificed on the $45^{\text {th }} \mathrm{dpi}$. These specimens were fixed in $10 \%$ formalin, dehydrated, cleared, and then embedded in paraffin blocks. Paraffin sections were taken of $5 \mu \mathrm{m}$ thickness, stained with haematoxylin and eosin (Hx \& E) and examined microscopically.

\section{Immunohistochemistry}

Automatic immunohistochemical staining was performed, applying a polymer-based detection system (DakoEnVision ${ }^{\mathrm{TM}}$ FLEX, K8000). Sections $(5 \mu \mathrm{m})$ from paraffin-embedded specimens were deparaffinized in xylene and then rehydrated in descending grades of alcohol. To block endogenous peroxidase activity, the sections were incubated in hydrogen peroxide 3\% for 5 minutes. The sections were then washed twice in PBS for 5 minutes each. For antigen retrieval, tissue sections were retained in $0.01 \mathrm{~mol} / \mathrm{l}$ citrate buffer $(\mathrm{pH} 6)$ in a water bath (Dako PT link) to be followed by incubation with the primary antibody murine anti-human CD4+ monoclonal antibodies (Dako, USA) at room temperature for one hour, then the sections were washed 3 times in PBS/ each for 15 minutes. Then, biotinylated goat anti-polyvalent secondary antibody and streptavidin peroxidase enzyme were added consecutively for $10 \mathrm{~min}$ and then washed in PBS. The peroxidase activity was visualized with diaminobenzidine (DAB) chromogen applied for 5 min (Ramos-Vara \& Miller, 2014). Tissue sections were then rinsed, counterstained with haematoxylin, dehydrated, cleared in xylene, and mounted by DPX. Sections from the tonsils were used as positive control in concordance with the manufacturer's recommendation. Negative controls were handled as in previous steps except for the use of the primary antibody. T lymphocytes expressing membranous or cytoplasmic brownish immunostaining for CD4+ were considered positive.

\section{Image analysis by real-time quantitative morphocytometry}

The specific analysis was performed using the Leica Qwin 500 Image Analyzer (LEICA Imaging Systems Ltd., Cambridge, England). Optical density (OD) and area percentage was automatically calculated in 10 fields for CD4+ marker on a real-time image from the microscope that was connected to a video monitor.

\section{Statistical analysis}

Results were presented as mean and standard deviation (SD). Data were analyzed by IBM SPSS software version 28.0 (Armonk, NY: IBM Corp). One way analysis of variance on ranks (Kruskal-Wallis) test and Dunn's-Bonferroni post hoc test were done for multiple pairwise comparisons between the study groups. P-values $<0.05$ were considered statistically significant.

\section{Results}

Effect of P. granatum and amygdalin extracts on number of adult and larval stages of Trichinella spiralis infection, in comparison to albendazole:

\section{Superior effect of albendazole in eliminating intestinal adult stages}

All the treated groups showed a reduction in the number of adult worms in comparison to the control group. The highest reduction was observed in the albendazole group (A), followed by the combined group (C) and lastly the $P$. granatum and amygdalin+ cobalamin group (B). Pairwise, comparison between the study groups revealed statistically significant difference between the control group, and groups A and C, respectively (Table 1, Figure 1). 


\section{Combined therapy significantly decreases larval stage}

The number of larvae was reduced in all of the treated groups. The highest diminution in the count larval stages was detected in the combined group (C), followed by the albendazole group (A), then P. granatum and amygdalin+ cobalamin group (B). Statistically significant differences were demonstrated between the control group, and groups $A$ and $C$, respectively, and between groups B and C (Table 1, Figure 1).

Table 1. Effect of different treatments on parasitic stages and CD4 cells in intestinal and muscle tissues in the study groups.

\begin{tabular}{|c|c|c|c|c|}
\hline & \multicolumn{2}{|c|}{ Intestinal (Subgroup I) } & \multicolumn{2}{|c|}{ Muscle (Subgroup II) } \\
\hline & $\begin{array}{l}\text { Number of adults } \\
\text { mean } \pm S D / m L \text { intestinal } \\
\text { fluid }\end{array}$ & $\begin{array}{c}\mathrm{CD4}^{+} \text {Area } \% \\
\text { mean } \pm \text { SD }\end{array}$ & $\begin{array}{c}\text { Number of larvae } \\
\text { mean } \pm \text { SD/mL } \\
\text { homogenate }\end{array}$ & $\begin{array}{c}\mathrm{CD4}^{+} \text {Area } \% \\
\text { mean } \pm \text { SD }\end{array}$ \\
\hline Control group & $198.33 \pm 15.12$ & $2.95 \pm 0.58$ & $399.67 \pm 16.35$ & $7.63 \pm 0.55$ \\
\hline Group A & $16.83 \pm 2.32$ & $4.97 \pm 0.37$ & $39.67 \pm 2.58$ & $12.20 \pm 0.87$ \\
\hline Group B & $40.83 \pm 3.82$ & $1.15 \pm 0.25$ & $68.00 \pm 6.51$ & $3.80 \pm 0.65$ \\
\hline Group C & $18.67 \pm 1.86$ & $3.08 \pm 0.66$ & $22.33 \pm 3.27$ & $2.47 \pm 0.53$ \\
\hline
\end{tabular}
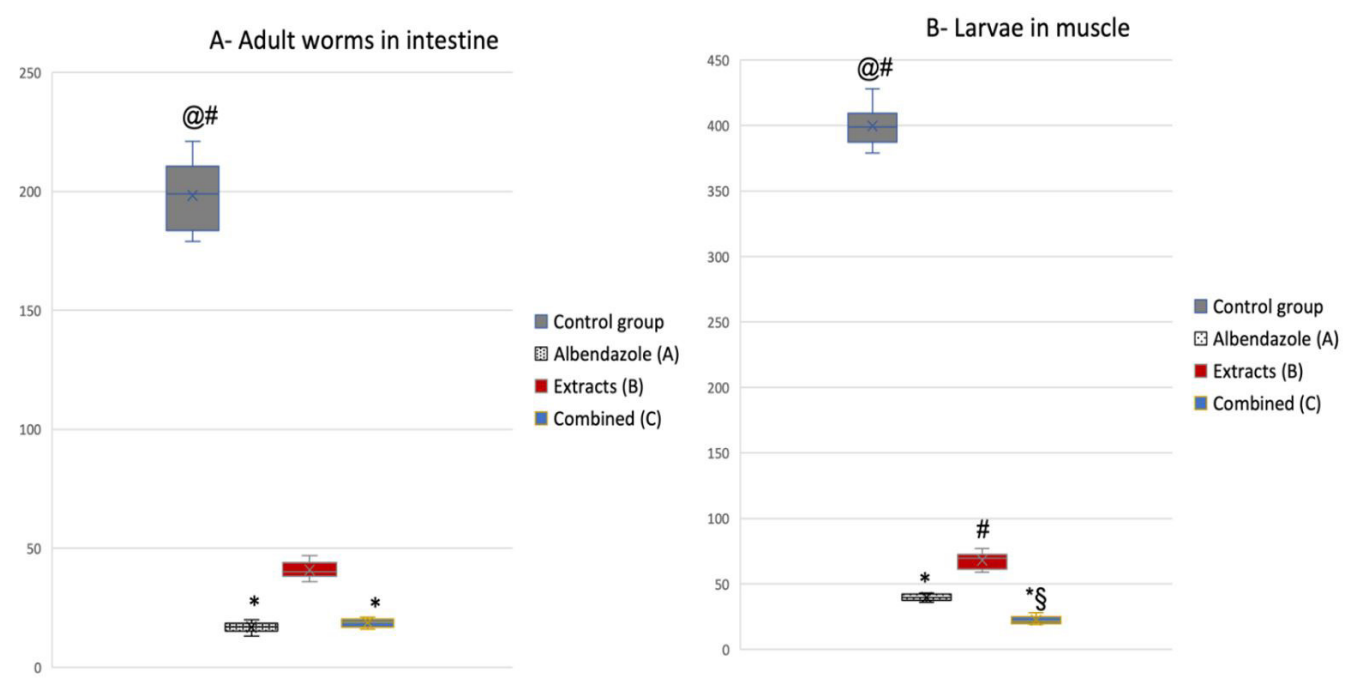

Figure 1. A boxplot representing the number of parasitic stages in different study groups. Statistical significance between groups, determined by Dunn's-Bonferroni post hoc test, is presented as: *, @, §, \# in relation to the control; albendazole; extracts; and combined groups, respectively.

Effect of $P$. granatum and amygdalin extracts on histopathological changes of Trichinella spiralis infection

\section{P. granatum and amygdalin extracts significantly reduce intestinal inflammatory reaction}

By histopathological examination, intestinal tissue of the control group exhibited a severe inflammation with necrotic severely inflamed villi, in addition to vacuolation indicating the degenerative effect of the parasitic stages. Compared to the control group, the albendazole group (A) displayed a relatively improved intestinal epithelium with epithelial vacuolation in some areas and numerous inflammatory cells. In contrast, intestinal tissue in P. granatum and amygdalin+ cobalamin and the combined groups (B and C) appeared almost healthy with normal villi and a mild inflammatory reaction (Figure 2).

\section{P. granatum and amygdalin extracts significantly diminish local inflammatory reaction within infected} muscle tissue

Histopathological examination of muscle tissue in the control group revealed intact larvae with surrounding moderate inflammatory response. In the albendazole group (A), muscle tissue demonstrated a severe inflammatory reaction enclosing the cystic parasitic lesions. While in the $P$. granatum/Amygdalin+ cobalamin group (B), the larvae were seen intact with adjacent mild inflammatory response in the muscle tissue. Degenerated larvae with a mild inflammatory reaction were observed in the combined group (C) (Figure 3). 


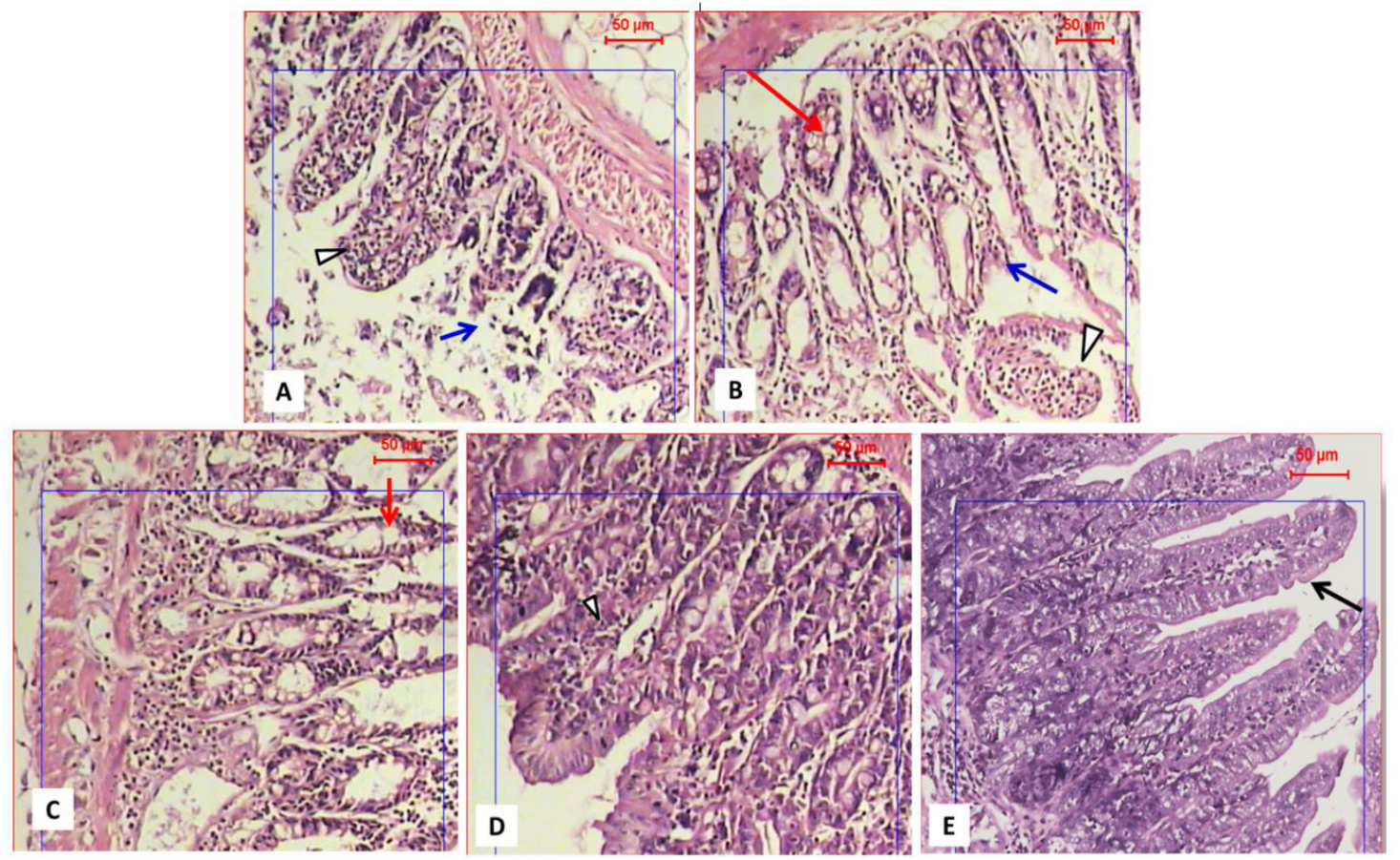

Figure 2. Histopathological examination of intestinal epithelium in different study groups. (A \& B) control groups showing shortening and necrosis (blue arrow), severe inflammation in villi (arrowhead), and vacuolation (red arrow); (C) albendazole treated group showing improved epithelium with sporadic vacuolation (red arrow); (D) natural remedies treated group demonstrating almost normal epithelium with mild inflammation (arrowhead). E; combined therapy group revealing normal length of the villi (black arrow) with mild inflammatory reaction (Hx \& E stain x200).
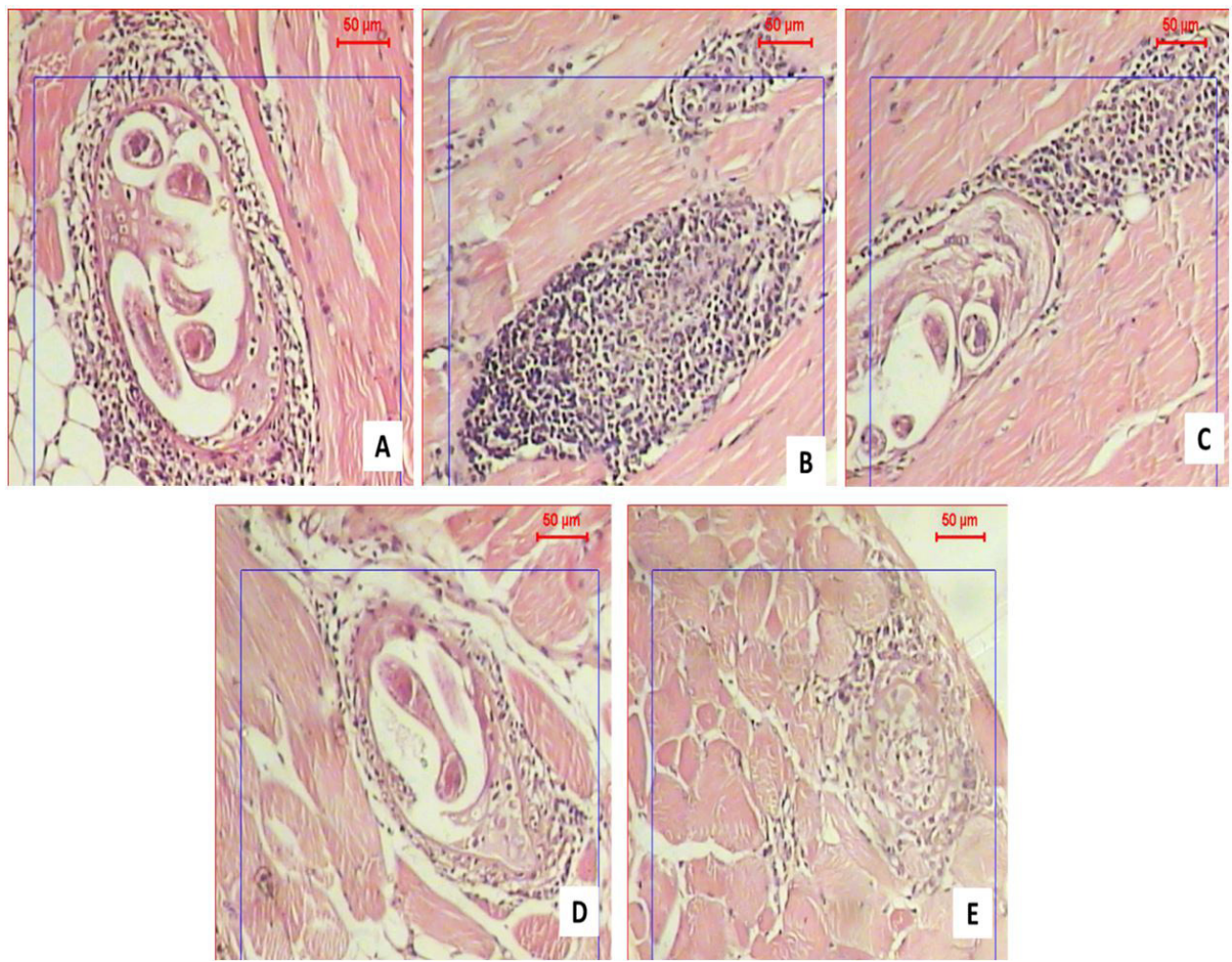

Figure 3. Cystic lesions in infected muscles of different study groups. (A) infected non treated control group showing intact larvae surrounded by moderate inflammatory response; (B \& C) albendazole treated group showing severe inflammatory response nearly encompassing the cystic parasitic lesions; (D) natural remedies treated group showing mild inflammation with apparently intact larva; (E) combined therapy group showing degenerated larva enclosed in mild inflammatory reaction (Hx \& E stain x200). 
Effect of $P$. granatum and amygdalin extracts on immunohistochemical changes of Trichinella spiralis infection

P. granatum/amygdalin extracts significantly downgrade local expression of CD4+ cells in infected intestinal tissue

Compared to the control group, albendazole group (A) demonstrated an increase in the expression of CD4+ cells, while $P$. granatum and amygdalin+ cobalamin group (B) showed a reduction in CD4+ expression. The combined group $(C)$ revealed minimal difference from the control group. Pairwise comparison revealed statistically significant difference between group $A$ and $B($ Table 1, Figures 4 \& 5).

\section{P. granatum and amygdalin extracts significantly lower local expression of CD4+ cells in infected muscle tissue}

In comparison to the control group, both the combined group $(C)$ and the $P$. granatum and amygdalin+ cobalamin group (B) showed a decrease in the expression of CD4+ cells, while the albendazole group (A) showed an increased expression of $\mathrm{CD} 4+$ in muscle tissue. Pairwise comparison analysis revealed statistically significant differences between the albendazole group (A) and groups B and C, respectively, and between the control and group C (Table 1, Figures 4, 5).

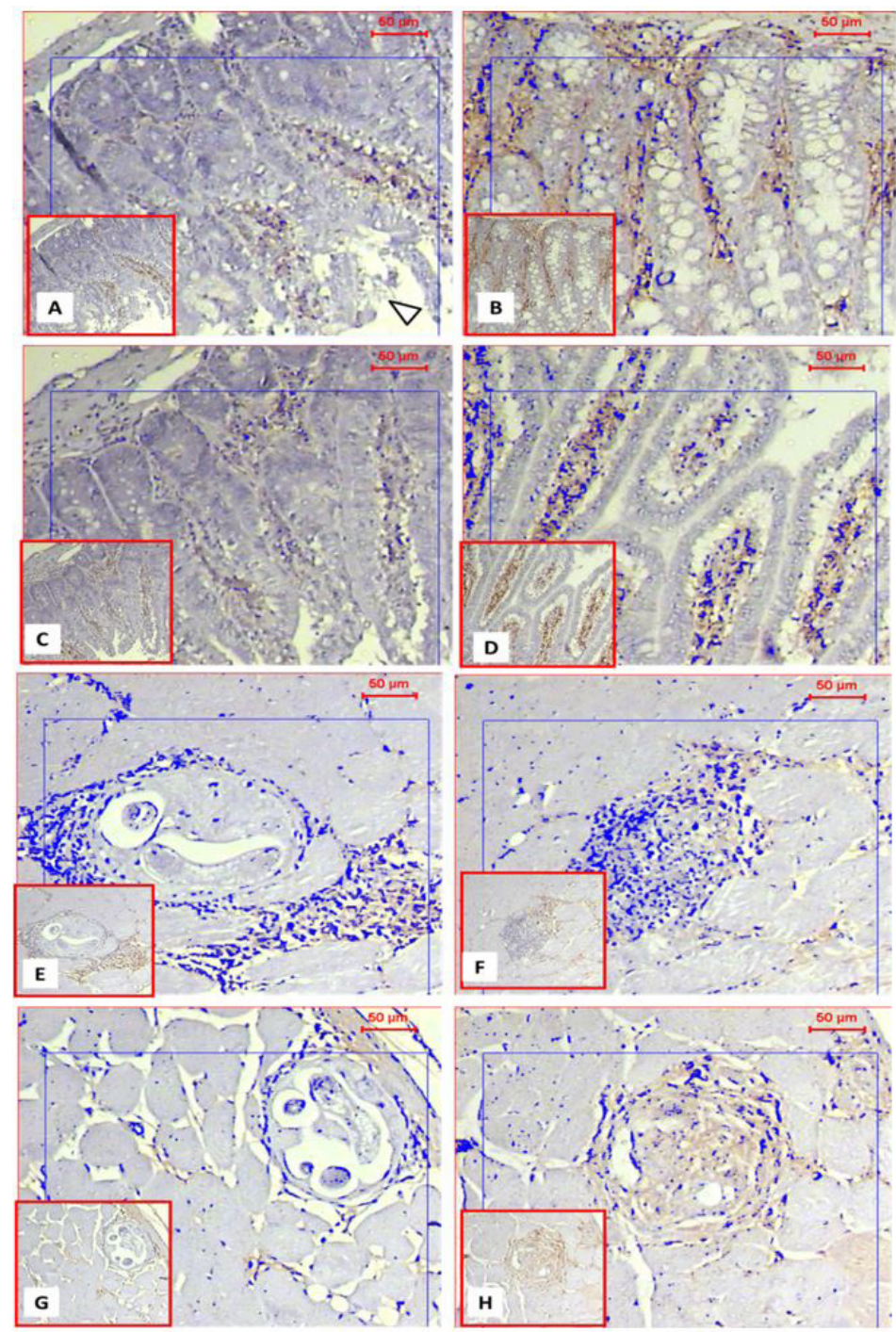

Figure 4. A to D; Local expression of CD4 within infected tissues of different groups. A; infected non treated group shows necrotic areas (arrow head) with moderate expression. Minimum expression appears within group C; group treated with natural remedies, while maximum expression exists in group B; treated with full dose Albendazole. Moderate expression be seen in group D; group treated with combined therapy (half Albendazole plus full dose of natural remedies. E to H; Photographs show local expression of CD4 within infected muscles of different groups. Minimum expression appears within group G; group treated with natural remedies, while maximum expression exists in group $\mathrm{E}$; infected non treated and group F; treated with full dose Albendazole. Moderate expression be seen in group $\mathrm{H}$; group treated with combined therapy (half Albendazole plus full dose of natural remedies (IHC x200). 


\section{A- Intestine CD4}

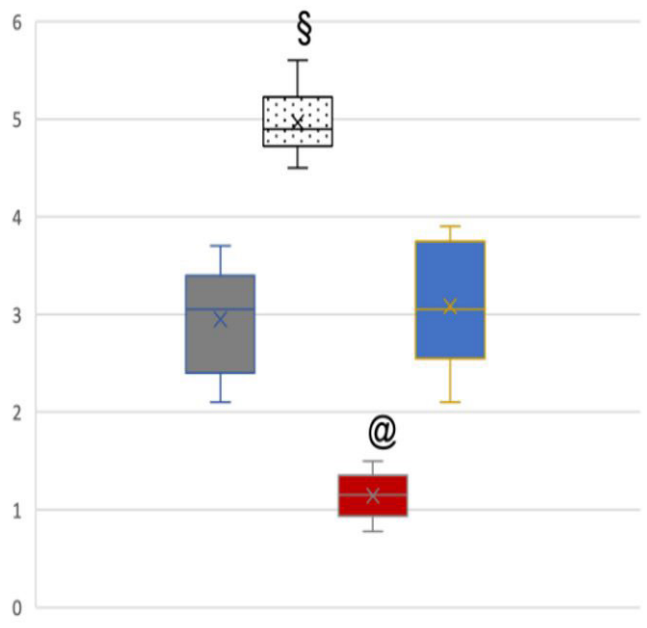

B- Muscle CD4



Figure 5. A boxplot representing the expression of CD4 within different study groups. Statistical significance between groups, determined by Dunn's-Bonferroni post hoc test, is presented as: *, @, §, \# in relation to the control; albendazole; extracts; and combined groups, respectively.

\section{Discussion}

Medical treatment of trichinellosis has been contested and challenged by the lack of a completely effective drug of choice. In order to achieve complete effectiveness, such a drug must act on all developmental stages of the parasite located in body organs (Dupouy-Camet et al., 2002). Since its introduction, albendazole has been pivotal for the treatment of many parasitic diseases; acting through various mechanisms, including inhibition of tubulin polymerization and fumarate reductase (Movahedi et al., 2017). Although being a broad spectrum anthelminthic, the low water solubility, and consequently poor bioavailability are limiting factors in albendazole usage (Hettiarachchi et al., 2016). Moreover, resistance to benzimidazoles, including albendazole, is increasingly reported globally (Dilks et al., 2020; Srivastava \& Misra-Bhattacharya, 2015). Over the years, plants have been key players in the development of new drugs (Yones et al., 2016). Plant extracts are a rich source of a large variety of biochemical active compounds which can impact several therapeutic targets (Anand et al., 2019; Ullah et al., 2020).

In the present work, we explored the therapeutic potentials of 2 medicinal plant extracts; $P$. granatum peel extract and amygdalin+ cobalamin in vivo, during both the intestinal phase and muscular phase of trichinellosis in comparison or/and in combination with albendazole monotherapy. Our results showed that $P$. granatum peel extract and amygdalin+ cobalamin reduced the number of parasites in intestine and muscle, but their effect was inferior to albendazole monotherapy. However, when these 2 plant extracts were used in combination with albendazole treatment, they achieved a significantly higher effect in muscle phase with more reduction in the larval count than albendazole monotherapy. Yet, the superior effect of plant extracts alone on reducing inflammatory response was clearly evident by the significant down regulation of CD4 within both intestinal and muscle tissues, indicating their potent anti-inflammatory effect.

Among various solvent extracts of $P$. granatum peel, ethanol extract was found to contain the highest antioxidant capacity. Phenols, tannins and flavonoids were noted as main active compounds in the extract that may confer antimicrobial, anthelminthic effects in addition to their antioxidant activity (Barathikannan et al., 2016; Castagna et al., 2020). Since it was first isolated from bitter almonds in 1830s, amygdalin exhibited an expansive range of therapeutic properties such as anti-inflammatory, antiangiogenic, antipyretic, antitussive and analgesic in treating several conditions including leprosy, migraine, hypertension and diabetes. Nevertheless, its benefit and use as an anti-cancer agent remains debatable (Jaswal et al., 2018; Saleem et al., 2018). Upon oral ingestion, amygdalin is hydrolyzed into glucose, benzaldehyde and hydrogen cyanide which can precipitate cyanide toxicity; yet the toxic dose is not clearly defined (Ayaz et al., 2020; Tř́sková \& Rudá-Kučerová, 2019). Vitamin B12 (cobalamin) has been proposed as a safe and effective antidote, it binds to cyanide forming cyanocobalamin which is excreted safely via the kidneys (Dang et al., 2017; Jaswal et al., 2018). 
Several studies have examined the effect of $P$. granatum peel extract on various intestinal helminths, and to a lesser extent on extra-intestinal helminths. For instance, Dkhil (2013) used a methanol extract of $P$. granatum peel to examine its anticoccidial and anthelminthic effects in vivo and in vitro, respectively. $P$. granatum peel was found to reduce Eimeria papillate output, improved the inflammation and vacuolation in jejunal epithelium in vivo and caused paralysis and death of adult Allolobophora caliginosa in vitro. While, (Abdel Aziz et al., 2018) study on Ascaridia galli showed that $P$. granatum peel aqueous extract had a closely similar effect to fenbendazole in vitro and a lower effect in vivo. Similarly, Castagna et al. (2020) highlighted the potential anthelminthic effect of $P$. granatum aqueous macerate, demonstrating an in vitro ovicidal activity against sheep intestinal nematodes. For extra-intestinal helminths, $P$. granatum peel and leaf extracts were shown to cause death of Schistosoma mansoni worms and schistosomules, both in vivo and in vitro (Fahmy et al., 2009). Recently, in their work on muscular phase of trichinellosis, Hafez et al. (2020) reported that $P$. granatum extract in methanol demonstrated a promising therapeutic effect, and suggested its use as an adjuvant with radiation-attenuated vaccine. Despite numerous studies having investigated the therapeutic properties of amygdalin, reports on its anti-parasitic effect are extremely limited.

Trichinella infection elicits an adaptive immune response where CD4+ T cells play a key role (Wang et al., 2020). Our findings revealed that $P$. granatum peel extract and amygdalin+ cobalamin treated group decreased local expression of CD4+ cells in the 2 phases of trichinellosis, in contrast to albendazole monotherapy which increased $\mathrm{CD} 4+$ expression in both phases. As for the combined group, the effect of $P$. granatum peel extract and amygdalin counteracted the effect of albendazole resulting in almost no change in CD4+ expression in the intestine, compared to the control group, while in muscle phase the resulting combined effect decreased the local expression of CD4+ cells.

Upon antigenic stimulation, activated CD4+ cells can differentiate into one of the following subset populations; Th1, Th2, Th17 or Treg. This differentiation is directed mainly by the cytokines present in the microenvironment. The relative proportions of each subset can change according to the course of infection (llic et al. 2012; Mousset et al., 2019; Sun et al., 2019). Early in the intestinal phase of trichinellosis, a strong CD4+ response of mixed Th1/Th2 subsets is induced in intestinal mucosa with predominance of Th2 cytokine profile (Ding et al., 2017). The resulting immunopathological alterations include mastocytosis and its degranulation, breaching the epithelial tight junctions and increased luminal fluid. Recently, TGF- $\beta$ was found to regulate CD4+ polarization into Th17 thereby enhancing intestinal muscle hypercontractility and propulsive activity leading to worm expulsion (llic et al., 2012; Steel et al., 2019). In muscle tissue, a local inflammatory response is formed around infected cells including numerous CD4+ cells with significant Th2, this response is influenced by the intestinal phase of the infection as it enhances myositis (Bruschi \& Chiumiento, 2011; Fabre et al., 2009). Parasite antigens induce Treg expression when encapsulation is formed, as a mechanism of immune evasion to ensure its survival within a regulatory microenvironment with high levels of TGF- $\beta$ and IL-10 (Ilic et al., 2012; Sun et al., 2019; Wang et al., 2020).

Punica granatum peel extract and amygdalin can interfere with Trichinella induced immune response through various immunomodulatory mechanisms. Both medicinal plants were found to reduce liver infiltration with CD4+ cells in autoimmune hepatitis (Elsaed, 2019; Wang et al., 2018). Additionally, amygdalin was also found to suppress TGF- $\beta$ in the context of fibrosis (Guo et al., 2013; Luo et al., 2016) and to inhibit proinflammatory cytokines TNF-a and IL-1 $\beta$ expression in arthritis (Hwang et al., 2008).

In conclusion, the present study revealed that $P$. granatum and amygdalin, alone and combined with albendazole had an inferior effect to albendazole alone regarding adults' worm burden, yet they evidently amended the intestinal pathology. However, their effect was more evident in muscle phase when combined with albendazole, achieving the highest reduction in larvae. In addition, P. granatum and amygdalin exerted a significant immunomodulatory effect in the form of a reduction of local CD4+ expression in the intestines as well as in muscle. These findings suggest that $P$. granatum and amygdalin can improve the therapeutic efficacy of albendazole specifically in muscle phase. Further detailed analysis is recommended regarding the mechanism of action of medicinal plants and their effect on different CD4+ subsets to benefit from their medicinal potentials.

\section{References}

Abdel Aziz AR, AbouLaila MR, Aziz M, Omar MA, Sultan K. In vitro and in vivo anthelmintic activity of pumpkin seeds and pomegranate peels extracts against Ascaridia galli. Beni-Suef University Journal of Basic and Applied Sciences 2018; 7(2): 231-234. http://dx.doi.org/10.1016/j.bjbas.2018.02.003.

Al-Megrin WA. In vivo study of pomegranate (Punica granatum) peel extract efficacy against Giardia lamblia in infected experimental mice. Asian Pac J Trop Biomed 2017; 7(1): 59-63. http://dx.doi.org/10.1016/j.apjtb.2016.08.018. 
Anand U, Jacobo-Herrera N, Altemimi A, Lakhssassi N. A comprehensive review on medicinal plants as antimicrobial therapeutics: potential avenues of biocompatible drug discovery. Metabolites 2019; 9(11): 258. http://dx.doi.org/10.3390/metabo9110258. PMid:31683833.

Ayaz Z, Zainab B, Khan S, Abbasi AM, Elshikh MS, Munir A, et al. In silico authentication of amygdalin as a potent anticancer compound in the bitter kernels of family Rosaceae. Saudi J Biol Sci 2020; 27(9): 2444-2451. http://dx.doi.org/10.1016/j. sjbs.2020.06.041. PMid:32884428.

Bai X, Hu X, Liu X, Tang B, Liu M. Current research of trichinellosis in China. Front Microbio/ 2017; 8: 1472. http://dx.doi.org/10.3389/ fmicb.2017.01472. PMid:28824597.

Barathikannan K, Venkatadri B, Khusro A, Al-Dhabi NA, Agastian P, Arasu MV, et al. Chemical analysis of Punica granatum fruit peel and its in vitro and in vivo biological properties. BMC Complement Altern Med 2016; 16(1): 264. http://dx.doi.org/10.1186/ s12906-016-1237-3. PMid:27476116.

Bruschi F, Chiumiento L. Trichinella inflammatory myopathy: host or parasite strategy? Parasit Vectors 2011; 4(1): 42. http://dx.doi. org/10.1186/1756-3305-4-42. PMid:21429196.

Castagna F, Britti D, Oliverio M, Bosco A, Bonacci S, Iriti G, et al. In vitro anthelminthic efficacy of aqueous pomegranate (Punica granatum L.) extracts against gastrointestinal nematodes of sheep. Pathogens 2020; 9(12): 1063. http://dx.doi.org/10.3390/ pathogens9121063. PMid:33353177.

Conlan JV, Vongxay K, Khamlome B, Gomez-Morales MA, Pozio E, Blacksell SD, et al. Patterns and Risks of Trichinella Infection in Humans and Pigs in Northern Laos. PLoS Neg/ Trop Dis 2014; 8(7): e3034. http://dx.doi.org/10.1371/journal.pntd.0003034. PMid:25078088.

Cui J, Wang J, Wang ZG, Niu HT. Minimum dose of Trichinella spiralis muscle larvae to infect mice. Zhongguo Ji Sheng Chong Xue Yu Ji Sheng Chong Bing Za Zhi 2008; 26(1): 73-74. PMid:18637592.

Dang T, Nguyen C, Tran PN. Physician Beware: Severe Cyanide Toxicity from Amygdalin Tablets Ingestion. Case Rep Emerg Med 2017; 2017: 4289527. http://dx.doi.org/10.1155/2017/4289527. PMid:28912981.

Dilks CM, Hahnel SR, Sheng Q, Long L, McGrath PT, Andersen EC. Quantitative benzimidazole resistance and fitness effects of parasitic nematode beta-tubulin alleles. Int J Parasitol Drugs Drug Resist 2020; 14: 28-36. http://dx.doi.org/10.1016/j. ijpddr.2020.08.003. PMid:32858477.

Ding J, Bai X, Wang X, Shi H, Cai X, Luo X, et al. Immune cell responses and cytokine profile in intestines of mice infected with Trichinella spiralis. Front Microbio/ 2017; 8: 2069. http://dx.doi.org/10.3389/fmicb.2017.02069. PMid:29163382.

Dkhil MA. Anti-coccidial, anthelmintic and antioxidant activities of pomegranate (Punica granatum) peel extract. Parasitol Res 2013; 112(7): 2639-2646. http://dx.doi.org/10.1007/s00436-013-3430-3. PMid:23609599.

Dunn IJ, Wright KA. Cell injury caused by Trichinella spiralis in the mucosal epithelium of B10A mice. J Parasitol 1985; 71(6): 757766. http://dx.doi.org/10.2307/3281709. PMid:4093809.

Dupouy-Camet J, Kociecka W, Bruschi F, Bolas-Fernandez F, Pozio E. Opinion on the diagnosis and treatment of human trichinellosis. Expert Opin Pharmacother 2002; 3(8): 1117-1130. http://dx.doi.org/10.1517/14656566.3.8.1117. PMid:12150691.

Elsaed WM. Amygdalin (Vitamin B17) pretreatment attenuates experimentally induced acute autoimmune hepatitis through reduction of CD4+ cell infiltration. Ann Anat 2019; 224: 124-132. http://dx.doi.org/10.1016/j.aanat.2019.04.006. PMid:31100343.

Fabre MV, Beiting DP, Bliss SK, Appleton JA. Immunity to Trichinella spiralis muscle infection. Vet Parasito/ 2009; 159(3-4): $245-248$. http://dx.doi.org/10.1016/j.vetpar.2008.10.051. PMid:19070961.

Fahmy Z, El-Shennawy A, El-Komy W, Ali E, Abd El-Hamed S. Potential antiparasitic activity of pomegranate extracts against schistosomules and mature worms of Schistosoma mansoni: in vitro and in vivo study. Aust J Basic App/ Sci 2009; 3(4): 4634-4643. http://dx.doi.org/10.1016/s1201-9712(10)60263-9.

Gottstein B, Pozio E, Nöckler K. Epidemiology, diagnosis, treatment, and control of trichinellosis. Clin Microbiol Rev 2009; 22(1): 127-145. http://dx.doi.org/10.1128/CMR.00026-08. PMid:19136437.

Guo J, Wu W, Sheng M, Yang S, Tan J. Amygdalin inhibits renal fibrosis in chronic kidney disease. Mol Med Rep 2013; 7(5): 14531457. http://dx.doi.org/10.3892/mmr.2013.1391. PMid:23525378.

Hafez EN, El Kholy WAES, Amin MM. The potential protective role of gamma-irradiated vaccine versus Punica granatum treatment against murine trichinellosis. J Radiat Res (Tokyo) 2020; 13(1): 560-567. http://dx.doi.org/10.1080/16878507.2020.1777659.

Hettiarachchi G, Samanta SK, Falcinelli S, Zhang B, Moncelet D, Isaacs L, et al. Acyclic cucurbit[n]uril-type molecular container enables systemic delivery of effective doses of albendazole for treatment of SK-OV-3 xenograft tumors. Mol Pharm 2016; 13(3): 809-818. http://dx.doi.org/10.1021/acs.molpharmaceut.5b00723. PMid:26756920.

Hwang HJ, Lee HJ, Kim CJ, Shim I, Hahm DH. Inhibitory effect of amygdalin on lipopolysaccharide-inducible TNF-alpha and IL1 beta mRNA expression and carrageenan-induced rat arthritis. J Microbiol Biotechnol 2008; 18(10): 1641-1647. PMid:18955812. 
Ilic N, Gruden-Movsesijan A, Sofronic-Milosavljevic L. Trichinella spiralis: shaping the immune response. Immunol Res 2012; 52(1-2): 111-119. http://dx.doi.org/10.1007/s12026-012-8287-5. PMid:22392054.

Jaswal V, Palanivelu J, Ramalingam C. Effects of the Gut microbiota on Amygdalin and its use as an anti-cancer therapy: substantial review on the key components involved in altering dose efficacy and toxicity. Biochem Biophys Rep 2018; 14: 125-132. http:// dx.doi.org/10.1016/j.bbrep.2018.04.008. PMid:29872744.

Juengel E, Thomas A, Rutz J, Makarevic J, Tsaur I, Nelson K, et al. Amygdalin inhibits the growth of renal cell carcinoma cells in vitro. Int J Mol Med 2016; 37(2): 526-532. http://dx.doi.org/10.3892/ijmm.2015.2439. PMid:26709398.

Liczbiński P, Bukowska B. Molecular mechanism of amygdalin action in vitro: review of the latest research. Immunopharmacol Immunotoxico/ 2018; 40(3): 212-218. http://dx.doi.org/10.1080/08923973.2018.1441301. PMid:29486614.

Luo H, Li L, Tang J, Zhang F, Zhao F, Sun D, et al. Amygdalin inhibits HSC-T6 cell proliferation and fibrosis through the regulation of TGF-ß/CTGF. Mol Cell Toxicol 2016; 12(3): 265-271. http://dx.doi.org/10.1007/s13273-016-0031-0.

Moneim AEA, Dkhil MA, Al-Quraishy S. Studies on the effect of pomegranate (Punica granatum) juice and peel on liver and kidney in adult male rats. J Med Plants Res 2011; 20(5): 5083-5088.

Moslehi A, Farahabadi M, Chavoshzadeh SA, Barati A, Ababzadeh S, Mohammadbeigi A. The effect of amygdalin on Endoplasmic Reticulum (ER) stress induced hepatic steatosis in mice. Malays J Med Sci 2018; 25(1): 16-23. http://dx.doi.org/10.21315/ mjms2018.25.1.3. PMid:29599631.

Mousset CM, Hobo W, Woestenenk R, Preijers F, Dolstra H, Van der Waart AB. Comprehensive phenotyping of T cells using flow cytometry. Cytometry A 2019; 95(6): 647-654. http://dx.doi.org/10.1002/cyto.a.23724. PMid:30714682.

Movahedi F, Li L, Gu W, Xu ZP. Nanoformulations of albendazole as effective anticancer and antiparasite agents. Nanomedicine (Lond) 2017; 12(20): 2555-2574. http://dx.doi.org/10.2217/nnm-2017-0102. PMid:28954575.

Pozio E, Zarlenga DS. New pieces of the Trichinella puzzle. Int J Parasitol 2013; 43(12-13): 983-997. http://dx.doi.org/10.1016/j. ijpara.2013.05.010. PMid:23816802.

Pozio E. World distribution of Trichinella spp. infections in animals and humans. Vet Parasitol 2007; 149(1-2): 3-21. http://dx.doi. org/10.1016/j.vetpar.2007.07.002. PMid:17689195.

Ramos-Vara JA, Miller MA. When tissue antigens and antibodies get along: revisiting the technical aspects of immunohistochemistry - the red, brown, and blue technique. Vet Patho/ 2014; 51(1): 42-87. http://dx.doi.org/10.1177/0300985813505879. PMid:24129895.

Saleem M, Asif J, Asif M, Saleem U. Amygdalin from apricot kernels induces apoptosis and causes cell cycle arrest in cancer cells: an updated review. Anticancer Agents Med Chem 2018; 18(12): 1650-1655. http://dx.doi.org/10.2174/187152061866618010516 1136. PMid:29308747.

Shalaby MA, Moghazy FM, Shalaby HA, Nasr SM. Effect of methanolic extract of Balanites aegyptiaca fruits on enteral and parenteral stages of Trichinella spiralis in rats. Parasitol Res 2010; 107(1): 17-25. http://dx.doi.org/10.1007/s00436-010-1827-9. PMid:20349194.

Sofronic-Milosavljevic L, Ilic N, Pinelli E, Gruden-Movsesijan A. Secretory products of Trichinella spiralis muscle larvae and immunomodulation: implication for autoimmune diseases, allergies, and malignancies. J Immunol Res 2015; 2015: 523875. http:// dx.doi.org/10.1155/2015/523875. PMid:26114122.

Srivastava M, Misra-Bhattacharya S. Overcoming drug resistance for macro parasites. Future Microbiol 2015; $10(11)$ : $1783-1789$. http://dx.doi.org/10.2217/fmb.15.73. PMid:26517758.

Steel N, Faniyi AA, Rahman S, Swietlik S, Czajkowska BI, Chan BT, et al. TGFß-activation by dendritic cells drives Th17 induction and intestinal contractility and augments the expulsion of the parasite Trichinella spiralis in mice. PLoS Pathog 2019; 15 (4): e1007657. http://dx.doi.org/10.1371/journal.ppat.1007657. PMid:30998782.

Sun XM, Guo K, Hao CY, Zhan B, Huang JJ, Zhu X. Trichinella spiralis Excretory-Secretory Products Stimulate Host Regulatory T Cell Differentiation through Activating Dendritic Cells. Cells 2019; 8(11): 1404. http://dx.doi.org/10.3390/cells8111404. PMid:31703440.

Třísková A, Rudá-Kučerová J. Can amygdalin provide any benefit in integrative anticancer treatment? Klin Onkol 2019; 32(5): 360366. http://dx.doi.org/10.14735/amko2019360. PMid:31610669.

Ullah F, Ayaz M, Sadiq A, Ullah F, Hussain I, Shahid M, et al. Potential role of plant extracts and phytochemicals against foodborne pathogens. App/ Sci (Basel) 2020; 10(13): 4597. http://dx.doi.org/10.3390/app10134597.

Wakelin D, Lloyd M. Accelerated expulsion of adult Trichinella spiralis in mice given lymphoid cells and serum from infected donors. Parasitology 1976; 72(3): 307-315. http://dx.doi.org/10.1017/S0031182000049507. PMid:967521.

Wang N, Bai X, Tang B, Yang Y, Wang X, Zhu H, et al. Primary characterization of the immune response in pigs infected with Trichinella spiralis. Vet Res 2020; 51(1): 17. http://dx.doi.org/10.1186/s13567-020-0741-0. PMid:32085808. 
Wang T, Men R, Hu M, Fan X, Yang X, Huang X, et al. Protective effects of Punica granatum (pomegranate) peel extract on concanavalin A-induced autoimmune hepatitis in mice. Biomed Pharmacother 2018; 100: 213-220. http://dx.doi.org/10.1016/j. biopha.2017.12.110. PMid:29428670.

Yadav AK, Temjenmongla. Efficacy of Lasia spinosa leaf extract in treating mice infected with Trichinella spiralis. Parasitol Res 2012; 110(1): 493-498. http://dx.doi.org/10.1007/s00436-011-2551-9. PMid:21748345.

Yones DA, Badary DM, Sayed HMB, Bayoumi SAH, Khalifa AA, El-Moghazy AM. Comparative evaluation of anthelmintic activity of edible and ornamental pomegranate ethanolic extracts against Schistosoma mansoni. BioMed Res Int 2016; $2016: 2872708$. http://dx.doi.org/10.1155/2016/2872708. PMid:27990425.

Zhang X, Wang ZQ, Wang SW, Li LZ, Wang MM, Jiang P, et al. Effect of vinegar or soy sauce on the infectivity and reproductive capacity of Trichinella spiralis muscle larvae. Zhongguo Ji Sheng Chong Xue Yu Ji Sheng Chong Bing Za Zhi 2010; 28(1): 34-37. PMid:20411747. 